UDC: 332.1

DOI: https://doi.org/10.32689/2617-

2224-2019-17-2-217-226

Naumenko Konstantin Valerievich, Senior Lecturer of the Department of Public Administration, Interregional Academy of Personnel Management, 03039, Kyiv, Str. Frometivska, 2, tel.: (044) 49095 00, e-mail:zuuber1978@ukr.net

ORCID: 0000-0002-7266-3829

Науменко Костянтин Валерійович, старший викладач кафедри публічного адміністрування, Міжрегіональна Академія управління персоналом, 03039, м. Київ, вул. Фрометівська, 2, тел.: (044) 49095 00,e-mail: zuuber1978@ukr.net

ORCID: 0000-0002-7266-3829

Науменко Константин Валерьевич, старший преподаватель кафедры публичного администрирования, Межрегиональная Академия управления персоналом, 03039, 2. Киев, вул. Фрометовская, 2, тел.: (044) 49095 00, e-mail: zuиber1978@ukr.net

ORCID: 0000-0002-7266-3829

\title{
METHODS OF PUBLIC ADMINISTRATION OF CIVIL SOCIETY
}

Abstract. In the present article, features of methods of public administration, which are used in the social environment, are considered. The international experience of normative and legal regulation of social activity is studied. The relationship between social phenomena and peculiarities of state administration in the historical, legal, social, and economic aspects is established. The effectiveness of domestic methods based on international experience has been investigated. The author presents his own classification of methods of state management of civil society. The definition of the concept of civil society as a phenomenon with developed economic, cultural, legal and political relations between its members, independent of the state that interacts with it is given. Hence, the methodology of theoretical and legal analysis of civil society covers all aspects of life, such as the processes of achieving freedom, equality, justice and other human values.

It is noted that the presence of problems in the state administration of Ukraine, in particular ineffective activity of institutes of state power and local self-government, corruption, lack of effective interaction between the state and civil society institutions is the result of ignoring objective scientific approaches 
to the formation of a coherent and logically well-established system of management of society; lack of a strategic vision for the improvement and development of the state and its institutes for the long-term and medium-term perspective; lack of methodology for adaptation and introduction of advanced foreign experience of public administration, especially the countries of the European Union. The solution of this problem on the path to the reform of public administration can be realized through the reform of political leadership.

Keywords: public administration, international experience, methods of public administration, civil society.

\section{МЕТОДИ ДЕРЖАВНОГО УПРАВЛІННЯ ГРОМАДЯНСЬКИМ СУСПІЛЬСТВОМ}

Анотація. Розглянуто особливості методів державного управління, які використовуються в суспільному середовищі. Досліджено міжнародний досвід нормативно-правового регулювання суспільної діяльності. Встановлено залежність між суспільними явищами та особливостями державного управління в історичному, правовому, соціальному та економічному аспектах. Досліджено ефективність вітчизняних методів на основі міжнародного досвіду. Представлено власну класифікацію методів державного управління громадянським суспільством. Надано визначення поняття громадянського суспільства як феномену з розвиненими економічними, культурними, правовими і політичними відносинами між його членами, незалежне від держави, який взаємодіє з ним. Методологія теоретико-правового аналізу громадянського суспільства охоплюе такі процеси, як досягнення свободи, рівності, справедливості та інших людських цінностей.

Зазначено, що наявність проблем в державному управлінні України, зокрема неефективна діяльність інститутів державної влади та органів місцевого самоврядування, корупція, відсутність ефективної взаємодії між державою та інститутами громадянського суспільства є наслідком ігнорування об'єктивних наукових підходів до формування цілісної та логічно правильно вибудованої системи управління суспільством; відсутністю стратегічного бачення удосконалення та розвитку держави та їі інститутів на довготривалу і середньотривалу перспективу; відсутністю методології адаптації та впровадження передового зарубіжного досвіду державного управління насамперед країн - членів Свропейського Союзу. Вирішення даної проблеми на шляху реформи державного управління може бути реалізовано через реформу політичного керівництва.

Ключові слова: державне управління, міжнародний досвід, методи суспільного управління, громадянське суспільство.

\section{МЕТОДЫ ГОСУДАРСТВЕННОГО УПРАВЛЕНИЯ ГРАЖДАНСКИМ ОБЩЕСТВОМ}

Аннотация. Рассмотрены особенности методов государственного управления, используемых в общественной среде. Исследован международный 
опыт нормативно-правового регулирования общественной деятельности. Установлена зависимость между общественными явлениями и особенностями государственного управления в историческом, правовом, социальном и экономическом аспектах. Исследована эффективность отечественных методов на основе международного опыта. Представлена собственную классификацию методов государственного управления гражданским обществом. Дано определение понятия гражданского общества как феномена с развитыми экономическими, культурными, правовыми и политическими отношениями между его членами, которое независимое от государства, взаимодействует с ним. Методология теоретико-правового анализа гражданского общества охватывает такие процессы, как достижение свободы, равенства, справедливости и других человеческих ценностей.

Отмечено, что наличие проблем в государственном управлении Украины, в частности неэффективная деятельность институтов государственной власти и органов местного самоуправления, коррупция, отсутствие эффективного взаимодействия между государством и институтами гражданского общества является следствием игнорирования объективных научных подходов к формированию целостной и логически правильно выстроенной системы управления обществом; отсутствием стратегического видения совершенствования и развития государства и его институтов на длительную и среднесрочную перспективу; отсутствием методологии адаптации и внедрения передового зарубежного опыта государственного управления прежде всего стран - членов Европейского Союза. Решение данной проблемы на пути реформы государственного управления может быть реализовано через реформу политического руководства.

Ключевые слова: государственное управление, международный опыт, методы общественного управления, гражданское общество.

Formulation of the problem. In the conditions of modern Ukraine, the mechanism of public administration of civil society should be improved.

This need is due not only to the logical positions regarding the management of civil society, but also to the need to improve the normative and legal regulation of social activities used in the social environment.

The legal essence of civil society, as a social phenomenon, develops in the context of the entire historical process as one of its sides. The formation of the logical construction of civil society implies the need for its legal analysis. This approach allows us to positively address the issues of civil society as a legal phenomenon. It should be emphasized that the law and all its elements are mainly investigated by means of legal science. The definition of the role of law in the provision of life, the structure of legal reality, and the methodological problems of the functioning of the legal system of society are given from the standpoint of jurisprudence. 
Civil society is a phenomenon with developed economic, cultural, legal, and political relations between its members, independent of the state interacting with it. Hence, the methodology of theoretical and legal analysis of civil society covers all aspects of life, such as the processes of achieving freedom, equality, justice, and other human values.

Most fully and vividly, the structure of the theoretical study of civil society, law, and state is shown in Table. It includes characteristics of civil society and its relations with law, the development of society under the influence of law and state, as well as the most impor- tant legal issues of the life of civil society. Political science differs from other ones by its specific subject of study, those aspect making the same phenomenon object of study of many sciences and caused by the need to integrate current knowledge about the interaction of law, state, and society. This fact makes us specially, albeit schematically, to include the legal interests to the interests of civil society, to identify the theoretical and legal perspective, and to distinguish it from the adjacent fields of social studies.

Law and order in the civil society are directly related with the mechanism of legal regulation and its main structural

\section{Structure of theoretical study of civil society}

\begin{tabular}{|c|c|c|c|}
\hline № & $\begin{array}{l}\text { Characterization of the civil } \\
\text { society and of its relation- } \\
\text { ships with law and state }\end{array}$ & $\begin{array}{l}\text { Development of civil soci- } \\
\text { ety under the influence of } \\
\text { law and state }\end{array}$ & $\begin{array}{l}\text { Study of the most impor- } \\
\text { tant legal issues of the civil } \\
\text { society life }\end{array}$ \\
\hline 1 & $\begin{array}{l}\text { The main directions of the } \\
\text { methodology of theoretical } \\
\text { and legal analysis of civil } \\
\text { society }\end{array}$ & $\begin{array}{l}\text { Strengthening the legal } \\
\text { framework of civil society }\end{array}$ & $\begin{array}{l}\text { Civil society as a subject of } \\
\text { legal studies }\end{array}$ \\
\hline 2 & $\begin{array}{l}\text { Extension of the interrela- } \\
\text { tions of law and state within } \\
\text { civil society }\end{array}$ & $\begin{array}{l}\text { Active role of the state of } \\
\text { law in the development of } \\
\text { civil society }\end{array}$ & $\begin{array}{l}\text { Methodological aspects of } \\
\text { civil society, law, and state }\end{array}$ \\
\hline 3 & $\begin{array}{l}\text { Development of legal rela- } \\
\text { tions with consideration of } \\
\text { the interests of civil society }\end{array}$ & $\begin{array}{l}\text { Perfection of the theoreti- } \\
\text { cal and legal mechanisms } \\
\text { of the interconnections be- } \\
\text { tween civil society and the } \\
\text { state }\end{array}$ & $\begin{array}{l}\text { Contractual theories of } \\
\text { formation of state and civil } \\
\text { society. Contemporary } \\
\text { contractualism. The para- } \\
\text { digm of a new vision of the } \\
\text { process of civil society and } \\
\text { state formation at the turn } \\
\text { of the XX-XXI centuries }\end{array}$ \\
\hline 4 & $\begin{array}{l}\text { Strengthening the relation- } \\
\text { ship between civil society, } \\
\text { individual, and law }\end{array}$ & $\begin{array}{l}\text { Changing the dynamics of } \\
\text { law and state relationship in } \\
\text { civil society }\end{array}$ & $\begin{array}{l}\text { Legal status of the individu- } \\
\text { al in civil society: historical } \\
\text { and contemporary aspects }\end{array}$ \\
\hline 5 & $\begin{array}{l}\text { Changing the balance of } \\
\text { private law in civil society }\end{array}$ & $\begin{array}{l}\text { Action of private law and } \\
\text { public law contracts }\end{array}$ & $\begin{array}{l}\text { Establishment and devel- } \\
\text { opment of private law in } \\
\text { Ukraine. Public-legal meth- } \\
\text { ods of relations regulation } \\
\text { in civil society }\end{array}$ \\
\hline
\end{tabular}

Developed by the author. 
elements - the norms of law, legal relationships, acts of realization of legal rights and responsibilities, and legal order, as a goal of legal regulation of social relations.

However, despite all correctness of the above points of view, the problem remains unresolved: the scope of the study included only those aspects of the study of the state which are legal in nature, but other ones connected with the analysis of the nature, origin of legal society, its social and legal nature and correlates, remain excluded.

Thus, the discovery of the nature of philosophy and law and the solution of the problem of the place and role of civil law within the system of modern humanities are not two separate problems but single one since only the analysis of civil society, social phenomena, and, above all, civil law, reveals the specifics of the legal study of such a phenomenon as the interaction of the institutions of the whole society. Otherwise, the naturalistic approach to social reality, civil society, and history, despite all declarations, may prove to be insurmountable. The very logic of the analysis of the connection between civil society and law appeals to the problems of jurisprudence, in accordance with the specifics of its knowledge of social phenomena, including legal ones.

Thus, despite the known number of scientific approaches to the civil society management, the problem of improving the methods of state governance remains unresolved, since there are no standardized mechanisms for the identification of the civil society needs, no criteria for such requirements, and no classification of the appropriate state governance mechanisms.
Analysis of recent research and publications. Recently, the state's economy has deteriorated severely.

The good point is the continuation of the cooperation with the IMF. If it continues, Ukraine may get $\$ 3,5$ billion tranche in 2018 which will help stabilize the hryvnia exchange rate and successfully repay its external debts.

In 2019, a moratorium ends on the payment of debt to private owners of Ukrainian bonds; into this period, presidential and parliamentary elections fall as well. That is why, year 2018 is the most comfortable for negotiations on the restructuring of external debt and postponement of payments.

Factors stimulating economic development: consumption and state expenditures, investments, net export. The main factor is investments stimulating the creation of jobs, of import-substituting industries, or of those which products are exported. In this case, foreign investments are very important. Every year, Ukraine needs to attract $\$ 20$ billion of investments in order to grow [1].

The basis of the scientific potential lies in scientific discoveries, thesis researches, scientific developments, and articles. However, with the informatization of the society, science becomes more accessible for citizens. According to the order of Ministry of Education and Science of Ukraine (hereinafter MES) № 1518 of October 31, 2013 [2], and to the Law № 2053-VIII of May 23, 2017 [3, p. 322], the availability of science for Ukrainians is increasing, as Law № 2053-VIII guarantees state support for the education of citizens with special needs at all levels - from school to university. This makes it, in 
turn, possible to employ the scientific potential of people with special needs.

Corruption is a widespread problem in Ukraine. [4] [5] In 2017, in the Transparency International's Corruption Perception Index, Ukraine ranked $131^{\text {st }}$ out of 176 countries surveyed (along with Myanmar and Mexico) [6]. Back in 2007, Ukraine ranked $118^{\text {th }}$ (out of 179 countries surveyed during the year) [7]. In 2012, international auditing company Ernst \& Young put Ukraine in the top three most corrupt countries in the world together with Colombia and Brazil [8]. The United States diplomatic service described Ukraine during the presidency of Leonid Kuchma and Viktor Yushchenko as kleptocracy, as it follows from the leakage of Wikileaks [9]. Since 2014, corruption in Ukraine has increased [10]. In April 2017, the same Ernst \& Young has put Ukraine first in the world in terms of corruption among the 41 countries surveyed (including Africa) [11] [12].

The main priorities of the state anticorruption policy in Ukraine should be defined in a special regulatory act - the Anti-Corruption Strategy. The AntiCorruption Agency has developed the Anti-Corruption Strategy for 20182020 [13].

The war in the east of Ukraine or the War at the Donbass is a military conflict launched by Russian troops that invaded Ukrainian Donbass' territories in April 2014 after the Crimea capture by the Russia, a series of pro-Russian appearances in Ukraine, and the proclamation of "state sovereignties" of "DPR" and "LPR". The conflict is of an international nature [14] and became a continuation of Russian armed aggres- sion against Ukraine. Its geographical scale is local; it covers the isolated districts of the Donetsk and Lugansk regions of Ukraine.

The presence of problems in the state governance of Ukraine, including ineffective activities of state institutions and local self-government institutions, corruption, lack of effective interaction between the state and civil society institutions, is a consequence of disregard of the objective scientific approaches to the formation of a coherent and logically well-established system of public administration; of lack of a strategic vision for the improvement and development of the state and its institutes for the long-term and mediumterm perspective; of lack of methodology for adaptation and introduction of advanced foreign experience of public administration, especially of the member states of the European Union.

The solution of this problem in course of the reform of public administration can be realized through the reform of political governance. Putting partners and civil society in a relationship of interdependence, as well as decentralization and transfer of public administration functions to lower levels of government, requires them to be able to perform these functions. Problems of coordination of the government functions also need to be addressed.

The purpose of the article is as follows: Analysis of the peculiarities of the implementation of the public administration methods used in the social environment; study of international experience of legal regulation of social activity; analysis of the relationship between social phenomena and peculiarities of state administration in histori- 
cal, legal, social, and economic aspects; study of the effectiveness of domestic methods of public administration based on international experience.

Presenting main study material. The need to investigate the problems of civil society is due to the fact that it serves as a kind of founder of a legal democratic state. This is especially true for transitional societies, where there are significant transformations and also a number of contradictions.

To this issue, the scientific works are devoted of many domestic scientists, such as M. O. Baimuratov, V. Yu. Barkov, V. V. Gorlenko [15], Yu. M. Oborotov [16, p. 58], M. P. Orzikh [17, p. 6768], V. F. Pogorilko, T. V. Rozova, Yu. M. Todyka [18, p. 187], O. F. Fryzsky etc. The mentioned authors pay attention to the processes of formation and interaction of civil society and the state of law - a democratic environment for the realization of civil values: freedom, justice etc. At the same time, it should be noted that the state of development and development of civil society in Ukraine is studied insufficiently in the doctrinal aspect. The basic conceptual provisions about the civil society were formulated by such prominent thinkers as J. Locke, A. Ferguson, S. L. Montesquieu, I. Kant, G. Hegel, A. de Tocqueville etc. Later, starting in the second half of the $19^{\text {th }}$ and the second half of the $20^{\text {th }}$ century, the phenomenon of civil society was almost forgotten, and only in the $80^{\mathrm{s}}$ of the XX century, it was remembered again in political practice. Despite all the diversity of interpretations of this phenomenon, the idea of civil society, according to Yu. M. Oborotov, was called for urgent need "to outline the range of such relations, which the state cannot interfere" [19, p. 58]. This opinion was followed by Yu. M. Todyka, who understood the civil society as "the system of individual social institutions independent from state and relations providing conditions for the realization of private interests and needs of individuals and groups, for the life of the social and spiritual spheres, for their reproduction and transmission from generation to generation" [20, p. 187]. But the most successful systemically and methodologically verified characteristic of civil society was given by M. P. Orzikh, who understands civil society as following: firstly, the association of people in which every person is free as having inalienable rights, is equal with other members of the association, and is independent in the choice of a civil status; secondly, non-state (institutionalized in public associations) associations of people by social, ethnic, religious, and other affiliation, political, as well as by economic, professional, and other interests; thirdly, the formation, on the above-mentioned principles, of social (non-state) relations developing and operating on a self-governing basis, as well as through the self-expression of the interests and will of separate individuals and their associations, operating in the law-free (free of state and legal influence) space of society [21, p. 67-68].

According to Article 1 of the Constitution of Ukraine, Ukraine is a democratic state of the law. However, in fact, for today, Ukraine is not such a state. This is primarily due to the fact that civil society has not yet been created in our country. After all, as you know, one of the four levels, in which democracy 
must be strengthened, apart from ideology, institutions, and culture, is a civil society [22].

The reason for this state of affairs is the lack of experience of the existence of a civil society or at least attempts to create it for many centuries of existence of the Ukrainian state.

Conclusions. Analysis of the peculiarities of the use of public administration methods in Ukraine has shown the absence of unified, standardized approaches, which testifies to the lack of perfect management policy.

The study of international experience in the regulation of social activity made it possible to highlight the most important aspects of public administration, in particular: the consolidation of civil society and government bodies; transparency of management activity of political circles; democratic nature of the political institutions of the state and politicians' credibility.

\section{REFERENCES}

1. Ishchenko A. (2018). Ukrainska ekonomika-2018: ryzyky, vyklyky ta mozhlyvosti [Ukrainian Economy-2018: Risks, Challenges and Opportunities]. ukr.segodnya.ua. Retrieved from https://ukr.segodnya.ua/economics/enews/ukrainskaya-ekonomika2018-riski-vyzovy-i-vozmozhnosti-1103384.html [in Ukrainian].

2. Nakaz Ministerstva osvity i nauky Ukrainy "Pro zatverdzhennia Vymoh do vyshchykh navchalnykh zakladiv ta zakladiv pisliadyplomnoi osvity, naukovykh, osvitno-naukovykh ustanov, shcho nadaiut osvitni posluhy za dystantsiinoiu formoiu navchannia z pidhotovky ta pidvyshchennia kvalifikatsii fakhivtsiv za akredytovanymy napriamamy i spetsialnostiamy" : vid
30.10.2013, № 1518 [Order of the Ministry of Education and Science "On the approval of the requirements for higher education institutions and institutions of postgraduate education, scientific, educational institutions providing educational services in the form of distance learning in preparation and advanced training of specialists in accredited areas and specialties" from 30.10.2013, № 1518]. (n.d.). zakon. rada.gov.ua. Retrieved from http://zakon.rada.gov.ua/laws/show/z1857-13 [in Ukrainian].

3. Zakon Ukrainy "Pro vnesennia zmin do Zakonu Ukrainy "Pro osvitu" shchodo osoblyvostei dostupu osib z osoblyvymy osvitnimy potrebamy do osvitnikh posluh" [The Law of Ukraine "On Amendments to the Law of Ukraine "On Education" regarding the peculiarities of access of persons with special educational needs to educational services”]. (2017). zakon.rada. gov.ua. Retrieved from http://zakon. rada.gov.ua/laws/show/2053-19 [in Ukrainian].

4. UAH $1.5 \mathrm{~b}$ in budget funds embezzled since year-start, interior minister says (June 18, 2009). Interfax-Ukraine [in English].

5. Ukrainians Pessimistic about Country's Future; Confidence in Political Leaders Falling (September 13, 2011). International Foundation for Electoral Systems [in English].

6. Bezkarnist ta nediieve pravosuddia trymaiut Ukrainu na koruptsiinomu dni [Impunity and ineffective justice hold Ukraine on the day of corruption]. (January 25, 2017). ti-ukraine. Retrieved from https://ti-ukraine. org/news/bezkarnist-ta-nediievepravosuddia-trymaiut-ukrainu-na-koruptsiinomu-dni/ [in Ukrainian].

7. Corruption Perceptions Index 2007 (2007). www.transparency.org. Retrieved from https://www.transpar- 
ency.org/research/cpi/cpi_2007/0 [in English].

8. Tkachuk V. (September 11, 2012). People First: The latest in the watch on Ukrainian democracy. www.kyivpost. com. Retrieved from https://www. kyivpost.com/article/opinion/op-ed/ people-first-the-latest-in-the-watchon-ukrainian-democracy-8-314837. html [in English].

9. Onyshkiv Yu. (September 2, 2011). Clearer Picture www.kyivpost.com. Retrieved from https://www.kyivpost.com/article/content/ukrainepolitics/clearer-picture-112083.html [in English].

10. Datsiuk S. (April 4, 2017). Koruptsiina stabilnist yak iliuziia [Corruption stability as an illusion]. blogs. pravda.com.ua. Retrieved from https://blogs.pravda.com.ua/authors/ datsuk/58e3457a818a8/ [in Ukrainian].

11. Datsiuk S. (April 11, 2017). Mozhlyvi naslidky neadekvatnosti [Possible consequences of inadequacy]. blogs.pravda.com.ua. Retrieved from https://blogs.pravda.com.ua/authors/ datsuk/58ec8d14f0338/ [in Ukrainian].

12. Reitynh koruptsii E\&Y: Ukraina na pershomu mistsi sered 41 krainy [E\&Y Corruption rate: Ukraine ranked first among 41 countries]. (April 10, 2017). ua-news.liga.net. Retrieved from https://ua-news.liga.net/politics/news/ reyting_korupts_e_y_ukra_na_na pershomu_m_sts_sered_41_kra_ni [in Ukrainian].

13. Uriad skhvalyv proekt Zakonu Ukrainy "Pro Antykoruptsiinu stratehiiu na 2018-2020 roky" [Government approved bill on the anti-corruption strategy for 2018-2020]. (April 25, 2018). www.kmu.gov.ua. Retrieved from https://www.kmu.gov.ua/ua/ news/uryad-shvaliv-proekt-zakonuukrayini-pro-antikorupcijnu-strate- giyu-na-2018-2020-roki [in Ukrainian].

14. Hnatovskyi M. (November 17, 2016). Koho pokaraie Mizhnarodnyi kryminalnyi sud? Mify ta realii zvitu shchodo Ukrainy [Who will be sentenced by the International Criminal Court? Myths and Reality of the Report on Ukraine]. www.eurointegration.com.ua. Retrieved from https://www.eurointegration.com.ua/ experts/2016/11/17/7057564/] [in Ukrainian].

15. Polityka [Politics]. (n.d.). www.narodnapravda.com.ua. Retrieved from www.narodnapravda.com.ua/politics [in Ukrainian].

16. Oborotov Yu. N. (Eds.). (2005). Teoriya gosudarstva i prava v voprosakh i otvetakh [Theory of State and Law in Questions and Answers]. Kharkiv: OOO "Odisey" [in Russian].

17. Kivalov S. V., Orzikh M. P. (Eds.). (2005). Osnovy pravoznavstva [Fundamentals of jurisprudence]. Odesa: Yurydychna literatura [in Ukrainian].

18. Todyka Yu. M., Zhurazskyi V. S. (Eds.). (2002). Konstytutsiine pravo Ukrainy [Constitutional Law of Ukraine]. Kyiv: In Yure [in Ukrainian].

19. Oborotov Yu. N. (Eds.). (2005). Teoriya gosudarstva i prava v voprosakh i otvetakh [Theory of State and Law in Questions and Answers]. Kharkiv: OOO "Odisey" [in Russian].

20. Kivalov S. V., Orzikh M. P. (Eds.). (2005). Osnovy pravoznavstva [Fundamentals of jurisprudence]. Odesa: Yurydychna literatura [in Ukrainian].

21. Todyka Yu. M., Zhurazskyi V. S. (Eds.). (2002). Konstytutsiine pravo Ukrainy [Constitutional Law of Ukraine]. Kyiv: In Yure [in Ukrainian].

22. Konstytutsiia Ukrainy [Constitution of Ukraine]. (1996). Vidomosti Verkhovnoi Rady Ukrainy - Bulletin of the Verkhovna Rada of Ukraine, 30 [in Ukrainian]. 


\section{СПИСОК ВИКОРИСТАНИХ ДЖЕРЕЛ}

1. Українська економіка-2018: ризики, виклики та можливості. Зазначив Амелін.

2. Наказ МОН від 30.10.2013 № 1518 Про затвердження Вимог до вищих навчальних закладів та закладів післядипломної освіти, наукових, освітньо-наукових установ, що надають освітні послуги за дистанційною формою навчання 3 підготовки та підвищення кваліфікації фахівців за акредитованими напрямами i спеціальностями / [Електронний ресурс]. - Режим доступу:http://zakon rada.gov.ua/laws/show/z1857-13

3. Закон України "Про внесення змін до Закону України “Про освіту” щодо особливостей доступу осіб з особливими освітніми потребами до освітніх послуг" // Відомості Верховної Ради України. - 2017. - № 30. Ст. 322 [Електронний ресурс]. - Peжим доступу: http://zakonrada.gov. ua/laws/show/2053-19

4. UAH $1.5 \mathrm{~b}$ in budget funds embezzled since year-start, interior minister says (англ.). Economy. Interfax-Ukraine (18 June 2009).

5. Ukrainians Ukrainians Pessimistic about Country's Future; Confidence in Political Leaders Falling (англ.). International Foundation for Electoral Systems (13 September 2011). Перевірено 10 квітня2016. Статичний 11 жовтня 2011 року.

6. Безкарність та недієве правосуддя тримають Україну на корупційному дні (укр.). ti-ukraine (25 янв. 2017).

7. Transparency International Corruption Perceptions Index 2007 Table

8. Viktor Tkachuk. People First: The latest in the watch on Ukrainian democracy (англ.). Kyiv Post (11 Sept. 2012).

9. Clearer Picture (англ.). Kyiv Post (2 September 2011).
10. Сергій Дащюк. Корупційна стабільність як ілюзія (укр.). Українська правда (4 апр. 2017).

11. Сергій Дачюк. Можливі наслідки неадекватності (укр.). Українська правда (11 апр. 2017).

12. Рейтинг корупції E\&Y: Україна на першому місці серед 41 країни (укр.). Ліга. Новости (10 апр. 2017).

13. Уряд схвалив проект Закону України "Про Антикорупційну стратегію на 2018-2020 роки”. [Електронний pecypc]. - Режим доступу: https:// www.kmu.gov.ua/ua/news/uryadshvaliv-proekt-zakonu-ukrayini-proantikorupcijnu-strategiyu-na-20182020-roki

14. Кого покарає Міжнародний кримінальний суд? Міфи та реалії звіту щодо України // Європейська правда. Процитовано 2017-01-22.

15. [Електронний ресурс]. - Режим доступу: www.narodnapravda.com.ua/ politics.

16. Теория государства и права в вопросах и ответах: учеб.-метод. пособие / Под ред. Ю.Н. Оборотова. - Х.: ООО “Одисей”, 2005. - С. 58.

17. Основи правознавства: навч. посіб. / За ред. С. В. Ківалова, М. П. Орзіха. - Одеса: Юрид. літ., 2005. C. 67-68.

18. Конституційне право України / За ред.: Ю. М. Тодики, В. С. Журавського. - К.: Ін Юре, 2002. - С. 187.

19. Теория государства и права в вопросах и ответах: учеб.-метод. пособие / Под ред. Ю. Н. Оборотова. - Х.: ООО “Одисей”, 2005. - С. 58.

20. Конституційне право України / За ред. Ю. М. Тодики, В. С. Журавського. - К.: Ін Юре, 2002. - С. 187.

21. Основи правознавства: навч. посіб. / За ред. С. В. Ківалова, М. П. Орзіха. - Одеса: Юрид. літ., 2005. C. 67-68.

22. Конституція України: Прийнята на V сесії Верховної Ради України 28 червня 1996. 